\title{
Studies of the Reticuloendothelial System (RES). III. Blockade of the RES in Man*
}

\author{
Henry N. Wagner, JR., and Masahiro Iio $\dagger$ \\ (From the Departments of Medicine and Radiology, The Johns Hopkins University School of \\ Medicine, Baltimore, Md.)
}

In a previous communication (1), we have presented data indicating that the phagocytic capacity of the reticuloendotheial system (RES) in man can be determined safely and effectively by measuring the rate of disappearance of various doses of radioisotopically labeled aggregated human serum albumin particles from the blood after intravenous injection. Subsequently we reported that in patients with pneumococcal pneumonia, typhoid fever, and pneumonic tularemia (2), the phagocytic capacity of the RES was increased as evidenced by an accelerated rate of clearance of the aggregated albumin (AA) from the blood. In contast, in both viral infections studied, dengue and sandfly fever (3), there was a temporary inhibition of the body's ability to clear aggregated albumin, a finding consistent with studies in experimental animals in which phagocytic ability was found to be inhibited by viral infections (4). The safety of the method has been further confirmed during studies of the relationship between RES phagocytic activity in man and endotoxin tolerance (5). To date, over 1,500 administrations have been made in over 300 individuals without untoward reactions of any type. Therefore, we extended the studies in an attempt to characterize in man the phenomenon of RES blockade, the latter being defined as retardation of the usual rate at which particulate matter is removed from the circulation (6).

In the present study, we have utilized in man and dog a modification of the technique employed by Murray in studies of rats (7). The RES was blockaded by administering various types of particles, and the effectiveness of blockade was tested by the subsequent injection of tracer doses of similar or dissimilar particles.

* Submitted for publication August 13, 1963 ; accepted March 19, 1964.

$\dagger$ U. S. Public Health Service trainee, National Institutes of Health grant H-6454.
In this report we will demonstrate that blockade of the RES in man as in experimental animals is relatively specific for the type of particle. Such specificity is not complete in that a significant depression of the clearance of dissimilar particles is noted, although to a far less degree than the depression of clearance of similar particles.

\section{Methods}

The particles used to produce blockade of the RES were AA prepared by the method described in a previous paper (1), gelatin, 1 and colloidal gold stabilized by gelatin. ${ }^{2}$ Radioactive colloids administered after blockade were $\mathrm{AA}$ labeled with $\mathrm{I}^{181}\left(\mathrm{AA}-\mathrm{I}^{121}\right),{ }^{2}$ radioactive colloidal gold, 2,3 and radioactive chromic phosphate $\left[\mathrm{Cr}_{2}\left(\mathrm{P}^{22} \mathrm{O}_{4}\right)_{3}\right] .^{3}$

Evaluation of blockade. After an initial control study of the rate of clearance of trace doses of particles, blockade was introduced by injecting intravenously 50 mg per $\mathrm{kg}$ of $\mathrm{AA}$ or gelatin in man and AA or colloidal gold in the dog. Test tracer doses of various particles were usually given at $30,60,120,180$, and 240 minutes after blockade. At times, tests were performed 8, 12, 24 , and 48 hours or several days after blockade. Blood samples were withdrawn from the antecubital vein in man or from the femoral artery of the dog at successive intervals ${ }^{4}$ after injection of the test dose. Radioactivity. of each sample was measured in a well-shaped crystal scintillation detector. Whole blood was used in the case of colloidal gold, and plasma that had been passed through an Amberlite IRA-400 anion exchange resin to remove free iodide in the case of AA- ${ }^{131}$ (1). A GeigerMüller counter was used for the measurement of radioactive chromic phosphate $\left(\mathrm{P}^{32}\right)$. The time required for removal of $50 \%$ of the circulating radioactivity after complete mixing (5 minutes after injection in man and 2 minutes in the dog) was taken as the half-time of clearance $\left(t_{3}\right)$, and the clearance rate constant $k$ was obtained from the equation $k=0.693 / t_{1}$ (1).

\footnotetext{
1 Knox gelatin protein products, Knox Gelatine Co., Johnstown, N. Y.

2 E. R. Squibb \& Sons, N. Y., N. Y.

3 Abbott Laboratories, North Chicago, Ill.

4 Two, four, six, eight and ten minutes after injection in the dog; five, seven, ten, and fifteen minutes in man.
} 


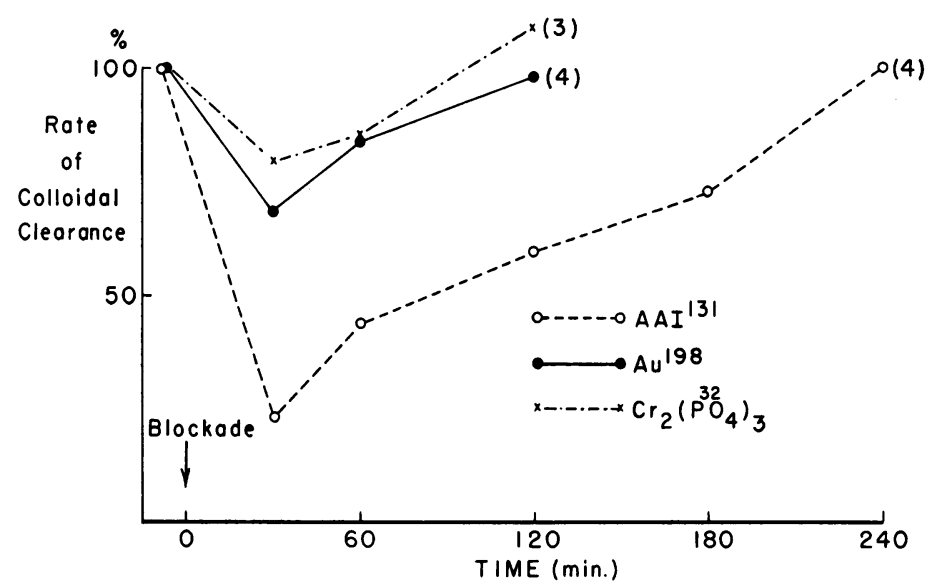

Fig. 1. Effect of Reticuloendothelial system (RES) BlockADE WITH AGGREGATEd ALBUMIN (AA) (50 MG PER KG) ON VARIOUS COLLOIDS IN MAN.

Subjects. All subjects were normal male volunteers without evidence of disease. Twenty-three subjects were given intravenously $50 \mathrm{mg}$ per $\mathrm{kg}$ of $\mathrm{AA}$. The effectiveness of this dose in producing RES blockade was examined by measuring the rate of clearance of trace doses ( $0.03 \mathrm{mg}$ per $\mathrm{kg}$ ) and $5 \mathrm{mg}$ per $\mathrm{kg}$ doses of $\mathrm{AA}-\mathrm{I}^{131}$ in four and six subjects, respectively. Trace doses of $\mathrm{Cr}_{2}\left(\mathrm{P}^{32} \mathrm{O}_{4}\right)_{3}$ were examined in three subjects and trace doses of colloidal gold ( $\mathrm{Au}^{188}$ ) in four others.

Eight subjects were given blockading doses of gelatin ( $50 \mathrm{mg}$ per $\mathrm{kg}$ ), and the effect of this substance was evaluated by test doses of AA- $\mathrm{I}^{131}$ in four subjects and by colloidal $\mathrm{Au}^{188}$ in four subjects.

Blockade was produced in two dogs with AA (50 mg per $\mathrm{kg}$ ) and in two dogs with colloidal gold (50 mg per $\mathrm{kg}$ ); the effectiveness of blockade was studied with AA-I ${ }^{131}$ and colloidal $\mathrm{Au}^{188}$.

No subjective reactions or objective signs were observed in any subjects given any of the colloidal materials.

\section{Results}

I. Blockade of the RES with $A A$. In Figures 1 and 2 and Table $I$ the effectiveness of blockade with AA is expressed as a percentage of the control clearance rate (initial value, $100 \%$ ) at various times after the intravenous blockading dose of AA ( $50 \mathrm{mg}$ per $\mathrm{kg}$ body weight). The clearance of subsequent trace doses of AA was markedly

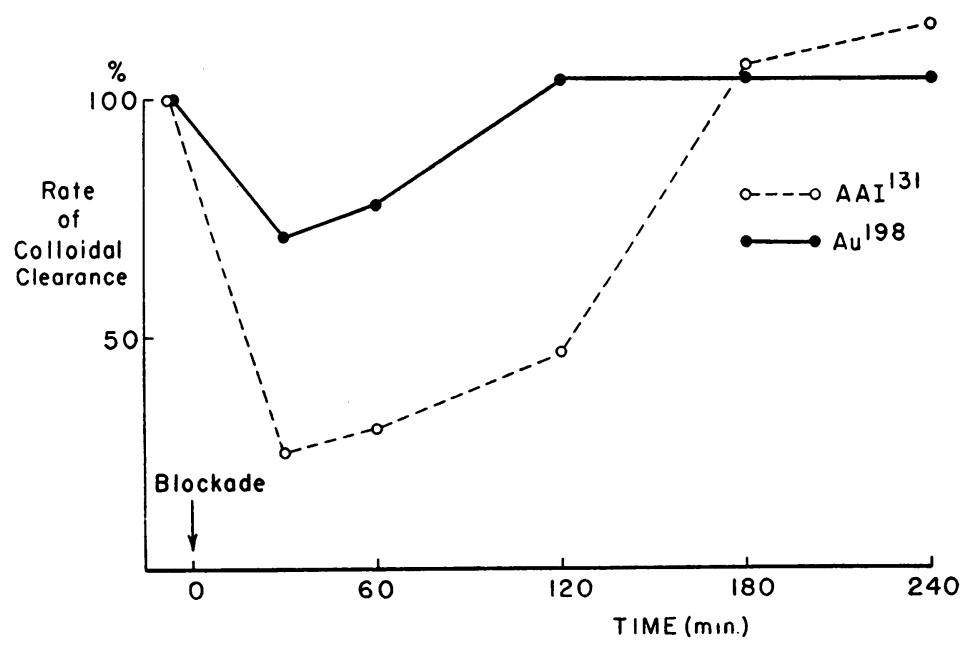

Fig. 2. EFFec of RES bi.Ockade With AA (50 Mg PER KG) ON VARIOUS COLI.OIDS IN DOG. 
TABLE I

Effect of blockade with aggregated albumin ( $A A, 50 \mathrm{mg}$ per $\mathrm{kg}$ ) on the clearance of various colloids in man*

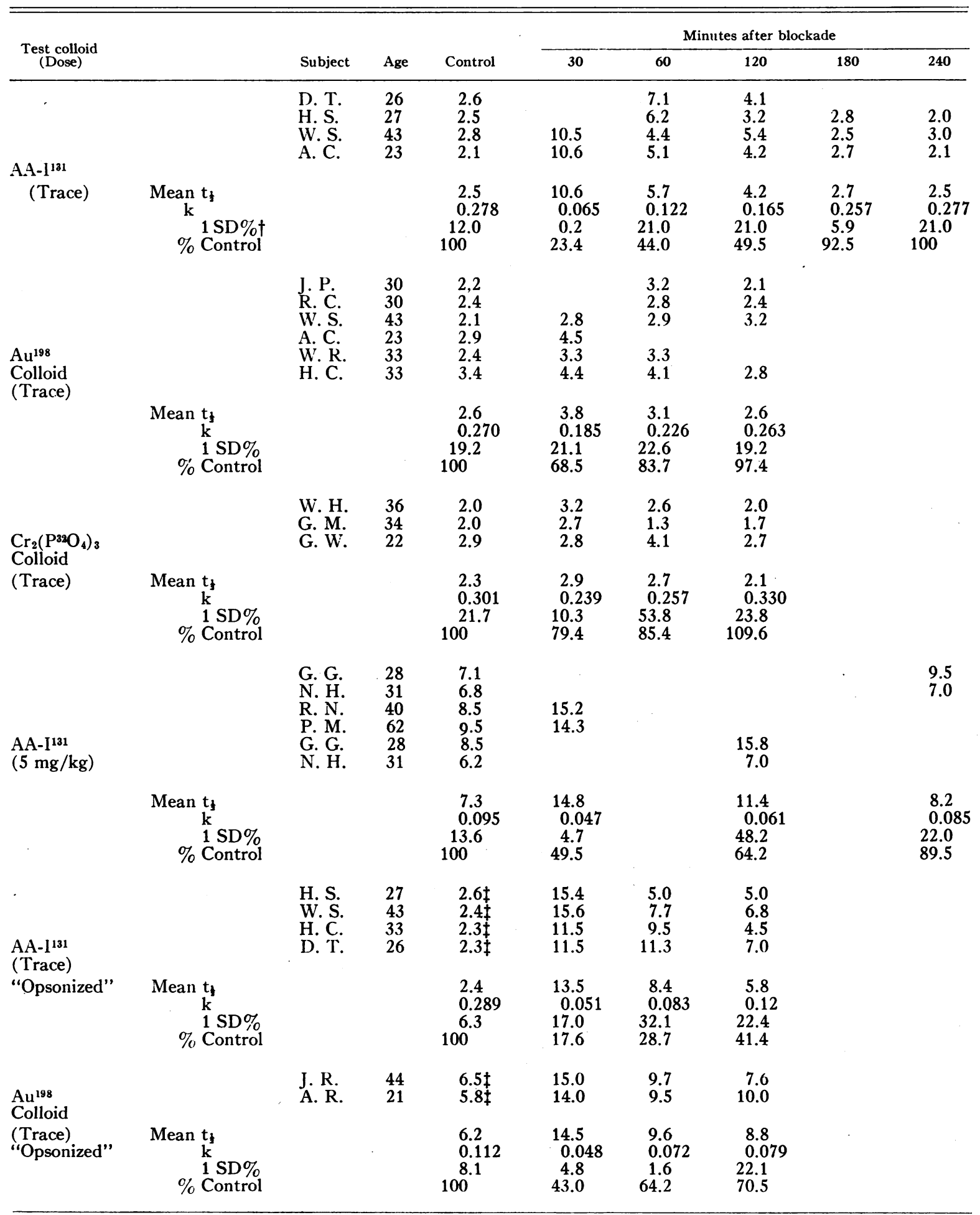

* Values represent the half-time of clearance in minutes.

$\dagger 1 \mathrm{SD} \%=$ relative standard deviation.

$\ddagger$ Control incubated saline and heparin at $37^{\circ} \mathrm{C}$ for 30 minutes. 
impaired. A significant but less striking effect was observed on subsequent clearances of colloidal gold and colloidal chromic phosphate. In man (Figure 1), AA blockade produced a $76 \%$ decrease in the clearance of $\mathrm{AA}$ at 30 minutes after blockade that lasted between 3 and 4 hours before returning to control values. On the other hand, AA blockade decreased colloidal gold and colloidal chromic phosphate clearances by only 31 and $20 \%$ respectively, at 30 minutes, and the duration of blockade did not exceed 2 hours. Similar results were obtained in six subjects (Table I) when $5 \mathrm{mg}$ per $\mathrm{kg}$ of $\mathrm{AA}-\mathrm{I}^{131}$ rather than a trace dose was used to test blockade.

Figure 2 illustrates the magnitude and duration of blockade produced by the intravenous injection of $50 \mathrm{mg}$ per $\mathrm{kg}$ aggregated albumin in the dog.

II. Blockade of the human RES with gelatin. Figure 3 and Table II illustrate that gelatin produced a more prolonged inhibitory effect on the clearance of subsequent doses of gelatin-stabilized $\mathrm{Au}^{198}$ than that observed with AA blockade. We also observed that gelatin blockade had a more pronounced effect on the clearance of gelatin-stabilized gold than on AA-I ${ }^{131}$.

Table III shows the relationship between doses of gelatin and duration of blockade on the clearance of colloidal gold (gelatin-stabilized) in man. With a dose of $10 \mathrm{mg}$ per $\mathrm{kg}$, recovery occurred within 24 hours ; with 50 and $250 \mathrm{mg}$ per $\mathrm{kg}$ doses, a blockading effect was still observed after 48 hours.

III. Blockade of the RES in the dog with colloidal gold. In Figure 4 the effectiveness of colloidal gold blockade of the dog on the clearance of subsequent test doses of colloidal $\mathrm{Au}^{198}$ and AA-I ${ }^{131}$ are illustrated. Although a markedly prolonged inhibition of clearance of $\mathrm{Au}^{198}$ was observed, the effect on the clearance of AA was of brief duration. Blockading doses of colloidal gold of this magnitude ( $50 \mathrm{mg}$ per $\mathrm{kg}$ ) resulted in the death of two of four dogs within 36 hours. One dog survived and cleared trace doses of $\mathrm{Au}^{198}$ normally 7 days after blockade.

\section{Discussion}

The present experiments indicate that the human RES can be safely and effectively blockaded by the administration of either aggregates of homologous serum albumin or gelatin. For study of RES blockade in man, AA has the advantage of nonantigenicity. We had reported evidence previously that AA is not antigenic in man (1), and this subsequent study has confirmed this. Recently Maurer (8) found evidence that gelatin and several derivatives of gelatin are weakly antigenic in both man and rabbit.

As far as we have been able to determine, RES blockade has not been produced and characterized in man previously, although the phenomenon of blockade has been studied in experimental animals (7). The technique of the present study, a modification of that of Murray (7), afforded certain important advantages. By measuring the rate of clearance of trace quantities of particulate matter, we were able to determine the duration of RES blockade, produced by larger ( $50 \mathrm{mg}$ per $\mathrm{kg}$ ) doses, since the trace doses themselves had no blockading effect. Consequently we were able to study each individual before, during, and after blockade, thereby eliminating some of the variability resulting from the use of different subjects at different times after blockade.

The use of trace doses of particles has a disadvantage in being less sensitive in detecting impairment of RES function than larger doses. This was evident in studies of viral infections in man where the clearance rates of $5 \mathrm{mg}$ per $\mathrm{kg}$ doses were impaired to a greater degree than the trace (0.03 mg per $\mathrm{kg}$ ) doses (3). The efficiency of phagocytosis in the liver and spleen is so great that the rate of clearance of trace doses is limited chiefly by hepatic and splenic blood flow rather than by the efficiency of the phagocytic cells of the RES. To be certain that impairment of the clearance of a trace dose of particles is not a manifestation of diminished RES blood flow, but rather an impairment of the phagocytic process at the cellular level, one must measure the clearance of various doses of the particles (1). In the present studies, the relative specificity of blockade made it possible to rule out impairment of blood flow as an important factor, since simultaneously administered particles of different type were cleared at normal or near normal rates. 


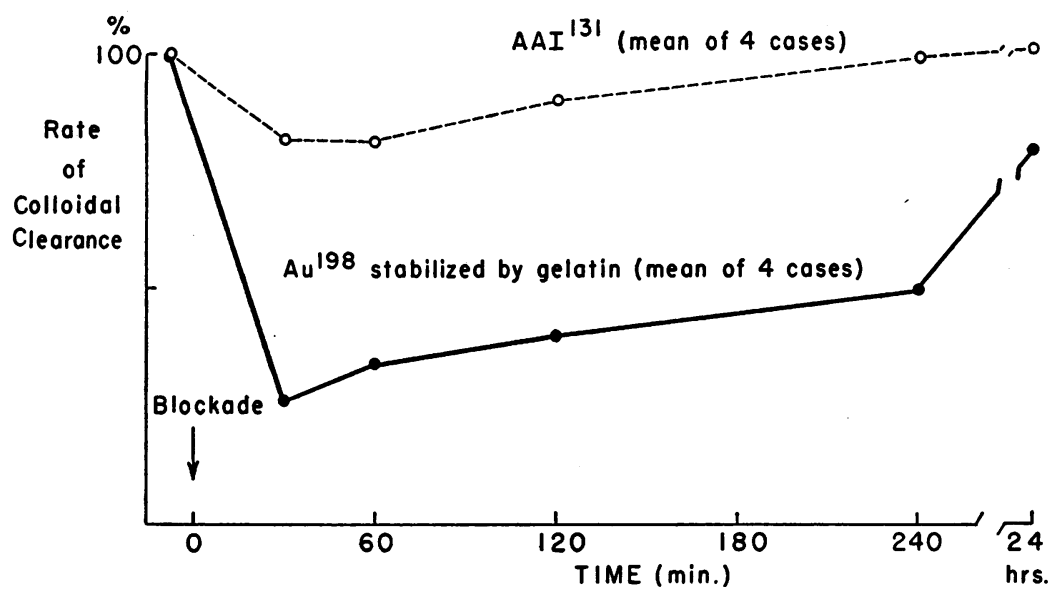

Fig. 3. EFFeCt of RES bLOCKAdE with Gelatin ( 50 Mg PER KG) ON AA-I 13 AND $A U^{108}$ COLLOID STABILIZED BY GELATIN IN MAN.

Using three different types of particles (AA and gelatin in man; $\mathrm{AA}$ and gelatin-stabilized colloidal gold in the dog) to produce blockade and three different substances to test for blockade (AA-I ${ }^{131}$, colloidal gold $\mathrm{Au}^{198}$, and colloidal chromic phosphate $\mathrm{P}^{32}$ in both man and dog), we were able to demonstrate specificity of blockade. Both magnitude and duration of blockade were greater with respect to the blockading particle than to other dissimilar particles. The specificity was not complete, but relative, since a smaller blockading effect on dissimilar colloids was observed.

Our observations of specificity of RES blockade in man are consistent with previously published data in experimental animals. Murray reported specificity of blockade on the blood clearance of various colloids (7). In our opinion, his failure to detect the slight blockading effect on dissimilar

TABLE II

Effect of blockade with gelatin $(50 \mathrm{mg} / \mathrm{kg}$ ) on the clearance of various colloids in man*

\begin{tabular}{|c|c|c|c|c|c|c|c|c|c|}
\hline \multirow{2}{*}{$\begin{array}{l}\text { Test } \\
\text { colloid } \\
\text { (Dose) }\end{array}$} & & \multirow[b]{2}{*}{ Subject } & \multirow[b]{2}{*}{ Age } & \multirow[b]{2}{*}{ Control } & \multicolumn{5}{|c|}{ Minutes after blockade } \\
\hline & & & & & 30 & 60 & 120 & 240 & $24 \mathrm{hrs}$ \\
\hline \multirow{2}{*}{$\begin{array}{l}\text { AA-I }{ }^{131} \\
\quad \text { (Trace) }\end{array}$} & & $\begin{array}{l}\text { D. C. } \\
\text { E. W. } \\
\text { D. B. } \\
\text { W. B. }\end{array}$ & $\begin{array}{l}43 \\
22 \\
38 \\
29\end{array}$ & $\begin{array}{l}3.5 \\
3.6 \\
2.8 \\
3.3\end{array}$ & $\begin{array}{l}4.2 \\
3.4 \\
2.5 \\
4.8\end{array}$ & $\begin{array}{l}3.6 \\
3.0 \\
4.7\end{array}$ & $\begin{array}{l}3.2 \\
3.4 \\
3.2 \\
3.7\end{array}$ & $\begin{array}{l}3.7 \\
3.0 \\
2.5 \\
3.0\end{array}$ & $\begin{array}{l}2.9 \\
2.7 \\
3.5\end{array}$ \\
\hline & $\begin{aligned} & \text { Mean } \mathrm{t}_{\mathbf{1}} \\
& \mathbf{k} \\
& \mathbf{1} \mathrm{SD} \% \\
& \% \text { Control }\end{aligned}$ & & & $\begin{array}{l}3.1 \\
0.227 \\
12.9 \\
100\end{array}$ & $\begin{array}{l}3.7 \\
0.186 \\
27.0 \\
81.9\end{array}$ & $\begin{array}{l}3.8 \\
0.184 \\
23.7 \\
81.1\end{array}$ & $\begin{array}{l}3.4 \\
0.205 \\
8.8 \\
90.3\end{array}$ & $\begin{array}{l}3.1 \\
0.226 \\
16.1 \\
99.6\end{array}$ & $\begin{array}{c}3.0 \\
0.229 \\
13.3 \\
100.9\end{array}$ \\
\hline \multirow{2}{*}{$\begin{array}{l}\mathrm{Au}^{198} \\
\text { Colloid } \\
\text { (Trace) }\end{array}$} & & $\begin{array}{l}\text { E. B. } \\
\text { M. C. } \\
\text { C. B. } \\
\text { R. D. }\end{array}$ & $\begin{array}{l}28 \\
26 \\
44 \\
25\end{array}$ & $\begin{array}{l}5.2 \\
4.1 \\
4.7 \\
3.2\end{array}$ & $\begin{array}{l}26.6 \\
13.5 \\
13.5 \\
12.5\end{array}$ & $\begin{array}{l}13.0 \\
11.0 \\
15.5 \\
12.0\end{array}$ & $\begin{array}{r}11.5 \\
13.3 \\
7.8\end{array}$ & $\begin{array}{r}12.3 \\
11.8 \\
6.5 \\
4.5\end{array}$ & $\begin{array}{l}6.5 \\
4.5 \\
7.8 \\
2.8\end{array}$ \\
\hline & $\begin{array}{rl}\text { Mean } & \mathbf{t}_{\mathbf{3}} \\
\mathbf{k} & \\
1 & \mathrm{SD} \% \\
\% & \text { Control }\end{array}$ & & & $\begin{array}{l}4.3 \\
0.161 \\
18.6 \\
100\end{array}$ & $\begin{array}{l}16.5 \\
0.042 \\
40.0 \\
26.1\end{array}$ & $\begin{array}{l}12.9 \\
0.054 \\
14.7 \\
33.6\end{array}$ & $\begin{array}{c}10.9 \\
0.064 \\
25.7 \\
39.8\end{array}$ & $\begin{array}{l}8.8 \\
0.079 \\
43.2 \\
29.1\end{array}$ & $\begin{array}{l}5.4 \\
0.128 \\
40.7 \\
79.5\end{array}$ \\
\hline
\end{tabular}

\footnotetext{
* Values represent the half-time of clearance.
} 


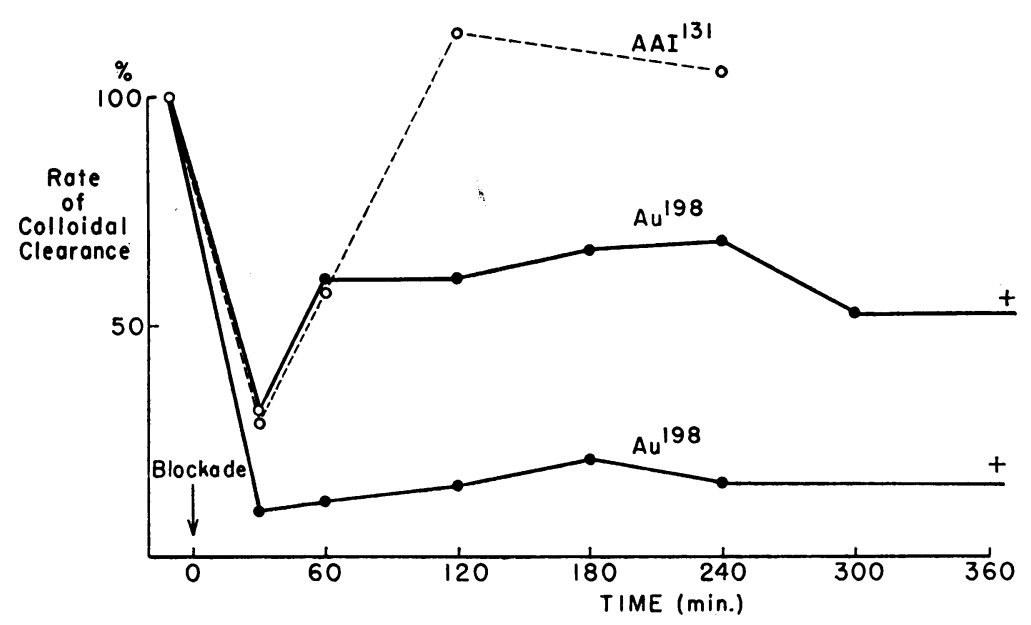

Fig. 4. EFfect of RES blockade with COLloidal gold (50 MG PER K(i) ON VARIOUS Colloins IN DOG. The + indicates that the dog died.

particles resulted from the fact that this effect is of short duration and of a magnitude difficult to detect without serial studies in the same animal. We cannot state at present whether specificity of blockade resulted from depletion of serum factors (opsonins) necessary for phagocytosis of inert particles (9).

Specificity of RES blockade at the cellular level can be supported by morphological examination. Petroff (10) injected carmine dye and colloidal silver and observed that some Kupffer cells contained only dye, whereas others contained only silver particles. Migay and Petroff (11) injected colloidal iron and carmine dye and found that the splenic macrophages contained chiefly the iron, whereas the liver macrophages ingested the dye particles. Schoenberg, Gilman, Mumaw, and Moore (12) observed that many RE cells were found to contain no polystyrene latex particles despite their proximity to other macrophages that were laden with the same particles as a result of intravenous injection. Perkins and Leonard (13) found that murine peritoneal macrophages ingested erythrocytes from various other species in a relatively specific fashion. Even after maximal phagocytosis induced by the presence of specific

TABLE III

Effect of blockade with various doses of gelatin examined by trace dose of $A u^{198}$ colloid in man

\begin{tabular}{|c|c|c|c|c|c|c|c|}
\hline \multirow[b]{2}{*}{ Dose } & \multirow[b]{2}{*}{. } & \multirow[b]{2}{*}{ Subject } & \multirow[b]{2}{*}{ Age } & \multirow[b]{2}{*}{ Control } & \multicolumn{3}{|c|}{ Hours after blockade } \\
\hline & & & & & 1 & 24 & 48 \\
\hline \multirow[t]{2}{*}{$10 \mathrm{mg} / \mathrm{kg}$} & & $\begin{array}{l}\text { J. D. } \\
\text { J. T. }\end{array}$ & $\begin{array}{l}30 \\
30\end{array}$ & $\begin{array}{l}4.3 \\
4.7\end{array}$ & $\begin{array}{r}14.0 \\
8.8\end{array}$ & $\begin{array}{l}3.8 \\
5.1\end{array}$ & \\
\hline & $\begin{array}{l}\text { Mean } \mathrm{t}_{\frac{1}{2}} \\
\quad \% \text { Control }\end{array}$ & & & $\begin{array}{l}4.5 \\
0.154 \\
100.0\end{array}$ & $\begin{array}{l}11.4 \\
0.061 \\
39.6\end{array}$ & $\begin{array}{l}4.5 \\
0.154 \\
100.0\end{array}$ & \\
\hline \multirow[t]{2}{*}{$50 \mathrm{mg} / \mathrm{kg}$} & & $\begin{array}{l}\text { C. L. } \\
\text { D. L. }\end{array}$ & $\begin{array}{l}24 \\
28\end{array}$ & $\begin{array}{l}2.0 \\
3.2\end{array}$ & $\begin{array}{l}9.9 \\
7.7\end{array}$ & $\begin{array}{l}5.9 \\
6.2\end{array}$ & $\begin{array}{l}3.3 \\
3.8\end{array}$ \\
\hline & $\begin{array}{l}\text { Mean } \mathrm{t}_{\frac{1}{2}} \\
\quad \% \stackrel{\text { Control }}{\%}\end{array}$ & & & $\begin{array}{l}2.6 \\
0.267 \\
100.0\end{array}$ & $\begin{array}{l}8.8 \\
0.079 \\
29.6\end{array}$ & $\begin{array}{l}\quad 6.1 \\
0.114 \\
42.7\end{array}$ & $\begin{array}{l}3.6 \\
0.210 \\
78.7\end{array}$ \\
\hline $250 \mathrm{mg} / \mathrm{kg}$ & & $\begin{array}{l}\text { J. H. } \\
\text { E. S. }\end{array}$ & $\begin{array}{l}33 \\
37\end{array}$ & $\begin{array}{l}4.1 \\
4.7\end{array}$ & $\begin{array}{r}21.0 \\
7.8\end{array}$ & & $\begin{array}{l}7.5 \\
7.5\end{array}$ \\
\hline - & 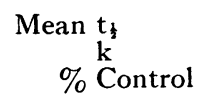 & & & $\begin{array}{l}4.4 \\
0.158 \\
100.0\end{array}$ & $\begin{array}{l}14.4 \\
0.048 \\
30.4\end{array}$ & & $\begin{array}{l}7.5 \\
0.092 \\
58.2\end{array}$ \\
\hline
\end{tabular}


immune opsonins, certain macrophages retained their preference for a subsequent nonopsonized species of erythrocyte. Only a few macrophages ingested more than one species of erythrocyte.

Thus, on the basis of kinetic and histologic evidence one may postulate that specificity of blockade results from the existence of different types of macrophages, each of which is particularly efficient at ingesting certain kinds of particles and much less efficient with others. Whether proliferation of $\mathrm{RE}$ cells is always general or involves only specific lines of macrophages is not known.

In the present experiments, as in previously reported data from animals, blockade wore off and phagocytic ability returned to normal after a period of time. The duration of blockade varies with different types of blockading particles. Recovery from blockade by AA occurred within 4 hours in man and 3 hours in the dog, whereas that produced by gelatin and colloidal gold was more prolonged. A possible basis for this more efficient handling of AA is the fact that it is readily metabolized after phagocytosis as evidenced by the appearance of free iodide and labeled peptide fragments in the urine shortly after the material has been ingested by hepatic and splenic macrophages. Recovery from blockade by AA may be related to the rate of catabolism of the particles within the macrophages. With nonmetabolizable particles, such as colloidal gold, duration of blockade is more prolonged. Gabrieli and Holmgren observed that a $50 \mathrm{mg}$ per $\mathrm{kg}$ dose of nonmetabolizable starch-stabilized colloidal iron produced an $83 \%$ depression of phagocytosis in the rat and that 7 days elapsed before phagocytosis returned to the original level (14). Benacerraf, Halpern, Biozzi, and Benos found that carbon (160 mg per $\mathrm{kg}$ ) produced a $50 \%$ impairment of phagocytosis of this particle and that 3 days were necessary before recovery (15). Stuart and associates reported that ethyl stearate blockade (750 $\mathrm{mg}$ per $\mathrm{kg}$ ) inhibited the phagocytosis of carbon $(80 \mathrm{mg}$ per $\mathrm{kg}$ ) for as long as 3 to 4 days (16). Metallic colloids such as silver have been found in Kupffer cells after 180 days (10). Carbon has been observed in macrophages for more than 500 days (17).

If one postulates that blockade by a particle that can be catabolized by the macrophages wears off as the particle is broken down, how can one explain the fact that nonmetabolizable particles do not produce permanent blockade? Benacerraf and his associates and Gabrielli and co-worker have proposed that proliferation of new macrophages is the principal factor in recovery from blockade by nonmetabolized particles $(15,14)$. However, Wiener, Wargaretten, and Spiro have been unable to find morphological evidence for this in electron micrographic examinations of blockaded animals (18). Rather than the formation of new macrophages, these investigators found vacuolization of thorium dioxide desposits enclosed by fine membranes. Possibly restoration of phagocytic function occurs when the energy and/or certain materials required for formation of the vacuolated conglomeration of particles have been repleted. Interference with the energy sources of the phagocytic cells has been observed to occur as a result of viral infections and may be a possible mechanism of the inhibitory effect that viral infections have on phagocytosis (3).

\section{Summary}

1) Blockade of the reticuloendothelial system (RES) in man was produced safely and effectively by the administration of large doses of either aggregated human serum albumin or gelatin.

2) Blockade of the RES was relatively specific, since the clearance of similar particles was inhibited to a greater degree and for longer duration than the clearance of dissimilar particles.

3) Specificity was not absolute, since a blockading effect of shorter duration and lesser magnitude was observed with dissimilar particles.

\section{Acknowledgments}

We thank Dr. Richard Hornick for his assistance in these studies and Dr. Sheldon Greisman for criticizing the manuscript.

\section{References}

1. Iio, M., and H. N. Wagner, Jr. Studies of the reticuloendothelial system (RES). I. Measurement of the phagocytic capacity of the RES in man and dog. J. clin. Invest. 1963, 42, 417.

2. Wagner, H. N., Jr., M. Iio, and R. B. Hornick. Studies of the reticuloendothelial system (RES). II. Changes in the phagocytic capacity of the RES in patients with certain infections. J. clin. Invest. 1963, 42, 427. 
3. Wagner, H. N., Jr., M. Iio, and R. B. Hornick. Inhibition of the phagocytic capacity of the human reticuloendothelial system in viral infections (abstract). J. clin. Invest. 1963, 42, 990.

4. Smorodintseff, A. A., and O. I. Shishkina. The mechanism of acquired immunity against influenza. II. The rôle of the phagocytic apparatus of actively immunized animals in the struggle with influenza virus. Arch. ges. Virusforsch. 1941, 2, 175.

5. Greisman, S. E., H. N. Wagner, Jr., M. Iio, and R. B. Hornick. Mechanism of endotoxin tolerance. II. Relationship between endotoxin tolerance and reticuloendothelial system phagocytic activity in man. J. exp. Med. 1964, 119, 241.

6. Biozzi, G., B. N. Halpern, B. Benacerraf, and C. Stiffel. Phagocytic activity of the reticuloendothelial system in experimental infections. Physiopathology of the RES. A symposium. Oxford, Blackwell Scientific Publications, 1957, p. 204.

7. Murray, I. M. The mechanism of blockade of the reticuloendothelial system. J. exp. Med. 1963, 117, 139.

8. Maurer, P. H. I. Antigenicity of oxypolygelatin and gelatin in man. J. exp. Med. 1954, 100, 497.

9. Jenkin, C. R., and P. Rowley. The role of opsonins in the clearance of living and inert particles by cells of the reticuloendothelial system. J. exp. Med. 1961, 114, 363.

10. Petroff, J. R. Zur Frage der Speicherung des kolloidalen Silbers im retikuloendothelialen System. Z. ges. exp. Med. 1924, 42, 242.
11. Migay, F., and J. R. Petroff. Über experimentell Erzeugte Eisenablagerurgen und vitale Karminfarbug bei Kaninchen. Arch. mikr. Anat. 1923, 97, 54.

12. Shoenberg, M. D., P. A. Gilman, V. R. Mumaw, and R. D. Moore. The phagocytosis of uniform polystyrene latex particles (PLP) by the reticuloendothelial system (RES) in the rabbit. Brit. J. exp. Path. 1961, 42, 486.

13. Perkins, E. H., and M. R. Leonard. Specificity of phagocytosis as it may relate to antibody formation. J. Immunol. 1963, 90, 228.

14. Gabrieli, E. R., and H. Holmgren. Studies in the blockage of the reticulo-endothelial system. Acta path. microbiol. scand. 1951, 31, 205.

15. Benacerraf, B., B. N. Halpern, G. Biozzi, and S. A. Benos. Quantitative study of the granulopectic activity of the reticuloendothelial system. III. The effect of cortisone and nitrogen mustard on the regenerative capacity of the R.E.S. after saturation with carbon. Brit. J. exp. Path. 1954, $35,97$.

16. Stuart, A. E., G. Biozzi, C. Stiffel, B. N. Halpern, and $\mathrm{P}$. Mouton. The stimulation and depression of reticuloendothelial phagocytic function by simple lipids. Brit. J. exp. Path. 1960, 41, 599.

17. Somerfeld, K. Utber das weitere Schicksal intravital gespeicherter Farbstoff. Z. ges exp. Med. 1930, $74,105$.

18. Wiener, J., W. Wargaretten, and D. Spiro. Fine structural studies of reticuloendothelial system (RES) blockade. Fed. Proc. 1963, 22, 672. 